\title{
Nutrient accumulation in Eucalyptus bark at different population densities
}

\author{
Thales G. V. Martins ${ }^{1}$, Maria F. V. Rocha ${ }^{2}$, Erick M. Nieri ${ }^{3}$, Lucas A. de Melo ${ }^{3}$, Maria L. de S. Silva ${ }^{4}$ \\ \& Diana S. N. da Silva ${ }^{3}$ \\ ${ }^{1}$ Universidade Federal de Viçosa/Departamento de Engenharia Florestal/Programa de Pós-Graduação em Ciência Florestal. Viçosa, MG. \\ E-mail: thales.eng.florestal@gmail.com (Corresponding author) - ORCID: 0000-0003-0921-0007 \\ ${ }^{2}$ Universidade Federal de Lavras/Departamento de Ciências Florestais/Programa de Pós-Graduação em Ciência e Tecnologia da Madeira. Lavras, \\ MG. E-mail: mfvrocha@yahoo.com.br - ORCID: 0000-0003-1297-4315 \\ ${ }^{3}$ Universidade Federal de Lavras/Departamento de Ciências Florestais/Programa de Pós-Graduação em Engenharia Florestal. Lavras, MG. E-mail: \\ erickenieri@yahoo.com.br - ORCID: 0000-0002-9425-9827; lucas.amaral@dcf.ufla.br - ORCID: 0000-0001-5219-9179; disuzete@yahoo.com.br - \\ ORCID: 0000-0001-9376-7945 \\ ${ }^{4}$ Universidade Federal de Lavras/Departamento de Ciências do Solo/Programa de Pós-Graduação em Ciência do Solo. Lavras, MG. E-mail: \\ marialigia.silva@dcs.ufla.br - ORCID: 0000-0003-1414-4219
}

\begin{abstract}
The objective of this study was to quantify the accumulation of nutrients in the bark of four eucalyptus clones at 12 years-of-age, planted at different population densities, and the values were extrapolated to $\mathrm{kg}$ of nutrients per hectare. The experiment used randomized blocks in a $4 \times 3$ factorial design and three replications, with four Eucalyptus clones (2486, I182, I144, and GG100) planted at three population densities $\left(416,833\right.$, and 1111 trees ha $\left.^{-1}\right)$. The rigorous cubage of three trees per plot was performed by collecting discs of bark at the following heights: diameter at breast height $(1.30 \mathrm{~m}), 0,25$, 50,75 , and $100 \%$ of the commercial height of the stem. The bark discs of each tree were grouped and used to determine $\mathrm{N}, \mathrm{P}, \mathrm{K}, \mathrm{Ca}, \mathrm{Mg}$, and S content, in addition to the basic density. The volume and dry mass of bark per tree was estimated and the accumulation of nutrients per tree ha ${ }^{-1}$ was estimated sequentially, for each population density. Analysis of variance and Tukey's post-hoc tests verified that Ca showed the greatest accumulation in the bark, followed by $\mathrm{N}, \mathrm{K}, \mathrm{S}, \mathrm{Mg}$, and P. The increase in population density contributed to higher bark production and greater nutrient accumulation per hectare. However, this increase was not evident when comparing densities of 833 and 1111 trees ha $^{-1}$.
\end{abstract}

Key words: compartmentalization, nutrient cycling, spacing

\section{Acúmulo de nutrientes na casca de Eucalyptus em diferentes densidades populacionais}

RESUMO: Objetivou-se neste trabalho quantificar o acumulo de nutrientes na casca de quatro clones de eucalipto, aos 12 anos, plantados em diferentes densidades populacionais, extrapolando os valores para $\mathrm{kg}$ de nutrientes por hectare. O delineamento experimental foi em blocos casualizados, em arranjo fatorial 4 x 3 com três repetições, sendo quatro clones de eucalipto (2486, I182, I144 e GG100), plantados em três densidades populacionais (416, 833 e 1111 plantas por hectare). A cubagem rigorosa de três árvores por parcela foi realizada por meio da coleta de discos de casca nas seguintes alturas: diâmetro à altura do peito $(1,30 \mathrm{~m}), 0,25,50,75$ e $100 \%$ da altura comercial do fuste. Os discos de casca de cada árvore foram agrupados e utilizados para determinar os teores de $\mathrm{N}, \mathrm{P}, \mathrm{K}, \mathrm{Ca}, \mathrm{Mg}$ e S, além da densidade básica. O volume e a massa seca de casca por árvore foram estimados e o acúmulo de nutrientes por árvore e hectare foi estimado sequencialmente, para cada densidade populacional. Os valores encontrados foram submetidos à análise de variância e ao teste de Tukey, verificando que o Ca foi o nutriente que apresentou o maior acúmulo na casca, seguido do N, K, S, Mg e P. O aumento da densidade populacional contribuiu para uma maior produção de casca e maior acúmulo de nutrientes por hectare. Entretanto, esse aumento não foi evidente ao comparar as densidades de 833 e 1111 árvores ha ${ }^{-1}$.

Palavras-chave: compartimentalização, ciclagem de nutrientes, espaçamento

Ref. 190775 - Received 26 Jan, 2018• Accepted 23 Sept, 2018 • Published 30 Nov, 2018 


\section{INTRODUCTION}

Since the 1990s, minimum cultivation systems have become widespread in the Brazilian forest sector, preserving the organic matter and exerting a significant positive effect on the nutrient dynamics of the ecosystem (Gatto et al., 2003; Selle, 2007; Silva et al., 2012). However, timber production has become more expensive in recent years because the forestry sector is operating below its productive capacity, making forest residues an alternative energy source in the industry. This new tendency towards the use of forest residues for energy production has again ignited discussions on the environmental and economic benefits of maintaining residues in the field and the concept of forest sustainability (Arruda et al., 2011; Viera et al., 2015; Salvador et al., 2016).

One of the benefits of maintaining forest residues on the soil is the reduction of nutrient exports, which is retained within the bark. Although the bark represents approximately $8 \%$ of the biomass of the Eucalyptus trunk, it contains about 18, 19, 21,60 , and $48 \%$ of $\mathrm{N}, \mathrm{P}, \mathrm{K}, \mathrm{Ca}$, and $\mathrm{Mg}$ content, respectively (Paes et al., 2013; Witschoreck \& Schumacher, 2015). These amounts reflect the importance of bark in nutrient cycling because a large portion of these nutrients are allocated to the tree and are usually removed from the site during logging.

When defining the appropriate management for each forest ecosystem, besides understanding the nutrient cycling process, knowledge of the factors that influence the export of nutrients from the soil is important. Population density is especially important since it modifies the water availability and affects the nutrient dynamics during the forest growth cycle. This relationship determines the number of trees to be planted and managed in the growing site (Leite et al., 1999; Schneider \& Schneider, 2008).

This study quantified the macronutrients present in the bark of four eucalyptus clones at 12 years-of-age, at three different population densities.

\section{Material ANd Methods}

The experiment was carried out in the city of Brasília de Minas, State of Minas Gerais, Brazil (Figure 1), on a Red Yellow Latosol (Oxisol). According to the Köppen classification, the climate of this region is Aw, with annual rainfall of approximately $1000 \mathrm{~mm}$ concentrated from November to March (Alvares et al., 2013).

The experiment was conducted in December 2003, with the planting of hybrid clones of Eucalyptus urophylla at different population densities. During the planting, $1000 \mathrm{~kg}$ of dolomitic limestone was applied over the total area, followed by harrowing to better incorporate the limestone, and subsoiling at a depth of $50 \mathrm{~cm}$ with continuous fillet phosphating, applying $400 \mathrm{~kg}$ of reactive phosphate at $20-\mathrm{cm}$ depth. The seedlings were treated with termiticides and the planting was performed manually.

In the basal fertilization, $100 \mathrm{~g}^{\text {tree }} \mathrm{e}^{-1}$ of NPK (06:30:06), plus $1 \%$ of $\mathrm{B}, \mathrm{Cu}$, and $\mathrm{Zn}$ were applied, followed by irrigation. The maintenance fertilization was applied at 4 and 12 months after planting using $150 \mathrm{~g}^{\text {tree }}{ }^{-1}$ potassium chloride at each stage.

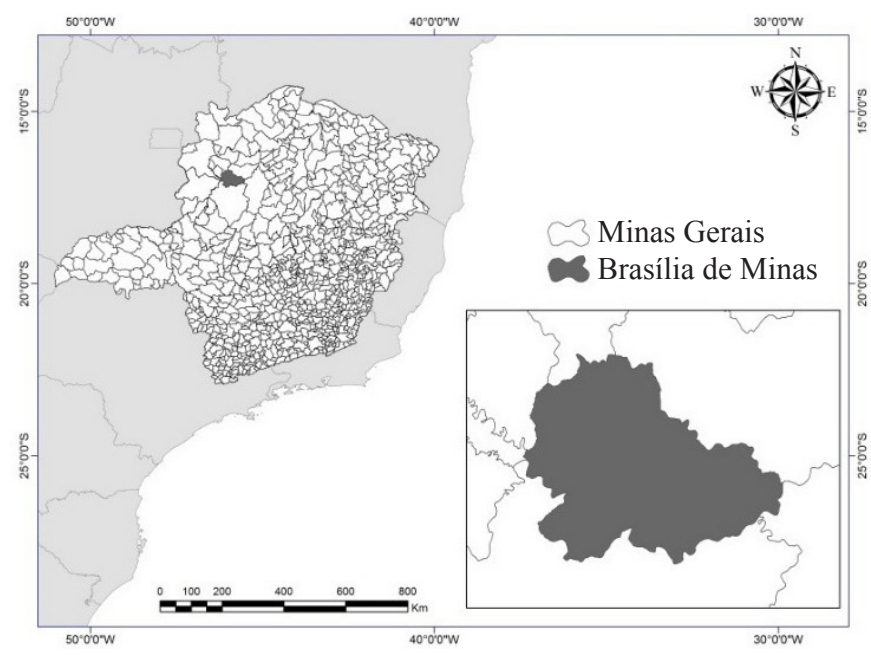

Figure 1. Study area, city of Brasília de Minas, northern Minas Gerais, Brazil

Maintenance fertilization was also performed by applying $27 \mathrm{~g} \mathrm{tree}^{-1}$ of Borogran, from March 2004 to March 2006.

The experiment was conducted in $500 \mathrm{~m}^{2}$ plots, in a complete randomized $4 \times 3$ factorial design and three replications, with four clones (2486, I182, I144, and GG100) and three population densities $\left(416,833\right.$, and 1111 trees ha $\left.^{-1}\right)$ in arrangements corresponding to $3 \times 8,3 \times 4$, and $3 \times 3 \mathrm{~m}$.

In February 2015, the diameter at breast height (DBH) of all the 12-year-old trees were measured using the forest inventory in each plot and three trees with a $\mathrm{DBH}$ close to the average were selected per plot to quantify $\mathrm{N}, \mathrm{P}, \mathrm{K}, \mathrm{Ca}, \mathrm{Mg}$, and $\mathrm{S}$ contents. These trees were cut and cubed, after removing six discs of bark at the DBH heights (1.30 m), and 0, 25, 50, 75, and $100 \%$ of the commercial stem height.

The diameters of the discs were measured with and without bark. The extracted barks were grouped by tree, and the macronutrient contents were determined, following the methodology described by Malavolta et al. (1997). The basic density of the bark was also determined (ABNT, 2003). The commercial height and the tree volumes were calculated using Smalian's formula and the disc diameters with and without bark (Colpini et al., 2009). The difference in bark volume was multiplied by the basic density to estimate the dry masses of bark per tree. The dry mass of bark was used to estimate the accumulation of nutrients present in the bark per tree and then extrapolated to per hectare using the population densities.

Once the normality statistical were attended, nutrient accumulation and bark production per hectare were analyzed using analysis of variance (ANOVA) and Tukey's test at a 0.05 probability, using R statistical software (R Core Team, 2016).

\section{Results AND Discussion}

Table 1 shows that there was a significant interactive effect between clone factors and population density for all variables, post-hoc investigations were conducted to determine which groups were different from each other.

Table 1 shows that the clones did not differ significantly in nutrient accumulation or bark production at the population density of 416 trees ha ${ }^{-1}$. Clones I182 and 2486 accumulated 
Table 1. Summary ANOVA and means for bark production and nutrient accumulation $\left(\mathrm{kg} \mathrm{ha}^{-1}\right)$ in the bark of Eucalyptus clones at 12-years-of-age at different population densities (trees ha-1)

\begin{tabular}{|c|c|c|c|c|c|c|c|}
\hline SV & Bark & $\mathbf{N}$ & $\mathbf{P}$ & K & $\mathrm{Ca}$ & Mg & $S$ \\
\hline \multicolumn{8}{|c|}{$\mathrm{kg} \mathrm{ha}^{-1}$} \\
\hline Clone (C) & ns & $\mathrm{ns}$ & * & ns & * & ns & ns \\
\hline P.D & * & * & * & * & * & * & * \\
\hline$C \times P . D$ & * & * & * & * & * & * & * \\
\hline \multirow[b]{2}{*}{ Clone } & \multicolumn{5}{|c|}{ Population density (P.D) } & \multirow{2}{*}{\multicolumn{2}{|c|}{$\begin{array}{c}\text { Mean } \\
\text { per clone }\end{array}$}} \\
\hline & 416 & & & 1111 & & & \\
\hline \multicolumn{8}{|c|}{ Bark $\left(\mathrm{kg} \mathrm{ha}^{-1}\right)$} \\
\hline 2486 & $5940 \mathrm{Ba}$ & 106 & & $7290 \mathrm{Bb}$ & & 796 & \\
\hline |182 & $4600 \mathrm{Ba}$ & 625 & & $12600 \mathrm{Az}$ & & 781 & \\
\hline I144 & $4290 \mathrm{Ba}$ & 740 & & $9730 \mathrm{Aab}$ & & 714 & \\
\hline GG100 & $5570 \mathrm{Ba}$ & & & $9660 \mathrm{Aab}$ & & 830 & \\
\hline Mean per P.D & 5100 & 849 & & 9820 & & CV (\%) & 18.49 \\
\hline \multicolumn{8}{|c|}{$\mathrm{N}\left(\mathrm{kg} \mathrm{ha}^{-1}\right)$} \\
\hline 2486 & $15.29 \mathrm{Ba}$ & 33. & & $25.25 \mathrm{AB}$ & & 24 & \\
\hline |182 & $14.35 \mathrm{Ba}$ & 15. & & $31.89 \mathrm{Aa}$ & & 20 & \\
\hline I144 & $13.25 \mathrm{Ba}$ & 23.1 & & $30.37 \mathrm{Aa}$ & & 22 & \\
\hline GG100 & $19.09 \mathrm{Ba}$ & 36. & & $30.14 \mathrm{AB}$ & & 28 & \\
\hline Mean per P.D & 15.50 & & & 29.41 & & CV (\%) & 27.46 \\
\hline \multicolumn{8}{|c|}{$\mathrm{P}\left(\mathrm{kg} \mathrm{ha}^{-1}\right)$} \\
\hline 2486 & $1.02 \mathrm{Aa}$ & 1.5 & & $0.90 \mathrm{Ab}$ & & 1. & \\
\hline |182 & $0.76 \mathrm{Ba}$ & & & $2.76 \mathrm{Aa}$ & & 1. & \\
\hline I144 & $0.96 \mathrm{Ba}$ & 2.0 & & $2.47 \mathrm{Aa}$ & & 1. & \\
\hline GG100 & $1.66 \mathrm{Ba}$ & 2.5 & & $2.59 \mathrm{Aa}$ & & 2. & \\
\hline Mean per P.D & 1.10 & & & 2.18 & & CV (\%) & 25.69 \\
\hline \multicolumn{8}{|c|}{$\mathrm{K}\left(\mathrm{kg} \mathrm{ha}^{-1}\right)$} \\
\hline 2486 & $8.46 \mathrm{Ba}$ & 14. & & $9.51 \mathrm{Ac}$ & & 10 & \\
\hline |182 & $7.44 \mathrm{Ba}$ & 11. & & $21.09 \mathrm{Aa}$ & & 13 & \\
\hline I144 & $8.20 \mathrm{Ba}$ & 10. & & $17.38 \mathrm{Aal}$ & & 12 & \\
\hline GG100 & $7.73 \mathrm{Ba}$ & 9.2 & & 13.26 Abc & & 10 & \\
\hline Mean per P.D & 7.99 & & & 15.31 & & CV (\%) & 23.18 \\
\hline \multicolumn{8}{|c|}{$\mathrm{Ca}\left(\mathrm{kg} \mathrm{ha}^{-1}\right)$} \\
\hline 2486 & $44.93 \mathrm{Ba}$ & 91. & & $64.61 \mathrm{AB}$ & & 67 & \\
\hline |182 & $36.84 \mathrm{Ba}$ & 60.9 & & $107.14 \mathrm{~A}$ & & 68 & \\
\hline I144 & $35.64 \mathrm{Ba}$ & 45. & & $77.69 \mathrm{Aal}$ & & 52 & \\
\hline GG100 & $32.30 \mathrm{Aa}$ & 56. & & $54.64 \mathrm{Ab}$ & & 47 & \\
\hline Mean per P.D & 37.43 & & & 76.02 & & CV (\%) & 25.90 \\
\hline \multicolumn{8}{|c|}{$\operatorname{Mg}\left(\mathrm{kg} \mathrm{ha}^{-1}\right)$} \\
\hline 2486 & 2.19 Ba & & & 2.67 Bb & & 3. & \\
\hline |182 & $2.07 \mathrm{Ba}$ & & & $6.44 \mathrm{Aa}$ & & 3. & \\
\hline I144 & $2.33 \mathrm{Ba}$ & 3.54 & & $4.39 \mathrm{Ab}$ & & 3. & \\
\hline GG100 & $2.97 \mathrm{Ba}$ & & & $4.30 \mathrm{ABb}$ & & 4. & \\
\hline Mean per P.D & 2.39 & & & 4.45 & & CV (\%) & 23.36 \\
\hline \multicolumn{8}{|c|}{$\mathrm{S}\left(\mathrm{kg} \mathrm{ha}^{-1}\right)$} \\
\hline 2486 & $5.22 \mathrm{Ba}$ & & & $6.49 \mathrm{Bb}$ & & 7. & \\
\hline |182 & $4.20 \mathrm{Ba}$ & & & $10.99 \mathrm{Aa}$ & & 6. & \\
\hline I144 & $3.73 \mathrm{Ba}$ & & & 8.71 Aab & & 6. & \\
\hline GG100 & $4.87 \mathrm{Ba}$ & & & $8.54 \mathrm{Aab}$ & & 7. & \\
\hline Mean per P.D & 4.51 & & & 8.68 & & CV (\%) & 16.83 \\
\hline
\end{tabular}

SV - Source of variation; C - Clone; P.D - Population density; CV - Coefficient of variation $G \times$ D.P - Interaction of clone and density factors; $n s$ - Not significant; *Significant by F test at 0.05 probability. The means followed by the same letter, upper case in the row and lower in the column, do not differ from each other by Tukey's test at 0.05 probability

lower amounts of nutrients at 833 and 1111 trees ha- ${ }^{-1}$, respectively. As spacing between trees became smaller, clones I182 and 2486 were more affected by increased intraspecific competition, resulting in lower nutrient accumulation and changes in biomass partitioning (Domec et al., 2017). Clone GG100 produced large amounts of bark at 833 and 1111 trees ha ${ }^{-1}$, even with lower nutrient amounts, indicating a greater use efficiency of these nutrients by this clone. This information can directly inform the selection of genotypes compatible with the soil fertility of the site and assist in maintaining the productive capacity of the forest site, especially for regions of low natural fertility. In practical terms, clones that are highly efficient in accumulating a specific element and planted in soils with low nutrient availability will rapidly adapt their productive capacity, if not fertilized (Santana et al., 2002).

When the behavior of clone 2486 at the three population densities was examined (Figure $2 \mathrm{~A}$ ), there was a greater production of bark at 833 trees ha $^{-1}$, which was significantly greater than that at 416 and 1111 trees ha $^{-1}$. There was higher nutrient accumulation in the bark at densities of 833 and 1111 trees ha ${ }^{-1}$, which was not significant, except for $\mathrm{Mg}$ and S, which were higher at 833 trees ha $^{-1}$.

For clone I182, there was a higher bark production and greater nutrient accumulation at 1111 trees $\mathrm{ha}^{-1}$, which was significantly higher than that at 833 and 416 trees ha $^{-1}$ (Figure $2 \mathrm{~B})$. In relation to clone $\mathrm{I144}$, higher bark production and greater accumulation of nutrients were observed at 833 and 1111 trees ha $^{-1}$, although this was not significantly different, except for $\mathrm{K}$ and $\mathrm{Ca}$, which showed higher accumulations at 1111 trees ha- ${ }^{-1}$. For clone GG100, higher bark production and greater nutrient accumulation were observed at 833 and 1111 trees ha ${ }^{-1}$, although there were no significant differences between them (Figure 2D).

There was an increase in bark production and nutrient accumulation as the planting density increased from 416 to 1111 trees ha $^{-1}$ (Figure 2C). Therefore, the higher the density, the higher the amounts of total nutrient accumulation in the bark per area. Depending on the harvesting system used, varying amounts of nutrients can be exported or retained in the soil through the bark of trees. However, the relationship between bark production and nutrient accumulation was variable between densities of 833 and 1111 trees ha ${ }^{-1}$, suggesting that bark production was more related to density when there is greater total nutrient accumulation per area than with the number of trees, as shown by clones 2486 and I182 (Figures 2A and B).

Barros et al. (1999) used only the physical and chemical characteristics of the soil and expected productivity as parameters to define the dose of fertilizer for Eucalyptus forests in the state of Minas Gerais, Brazil. However, the results in this study showed that population density can also be used as a criterion to determine the amount of fertilizer to be applied to guarantee the sustainability of forest production and to reduce the export of nutrients from the growing site.

The amount of nutrients present in the bark of the four clones ranged from $1.2 \%$ (GG100 at 1111 trees $\mathrm{ha}^{-1}$ ) to $1.6 \%$ (I182 at 833 trees ha ${ }^{-1}$ ) (Figure 3).

$\mathrm{Ca}$ accounted for more than half (47-62\%) in bark of the total nutrients accumulated, as it has low mobility and plays an important role in the lignification process in the cambial zone (Wernsdörfer et al., 2014). The next highest nutrient was $\mathrm{N}(15-31 \%)$, followed by K (8-13\%) (Figure 4).

Viera et al. (2015) evaluated the nutritional implications of different harvesting intensities on 10-year-old E. urophylla $\times E$. globulus hybrids at a density of 1142 trees per ha $\mathrm{a}^{-1}$ and found in the bark: $75 \mathrm{~kg} \mathrm{ha}^{-1} \mathrm{~N}, 15 \mathrm{~kg} \mathrm{ha}^{-1} \mathrm{P}, 131 \mathrm{~kg} \mathrm{ha}^{-1} \mathrm{~K}, 429 \mathrm{~kg} \mathrm{ha}^{-1}$ $\mathrm{Ca}, 92 \mathrm{~kg} \mathrm{ha}^{-1} \mathrm{Mg}$, and $11 \mathrm{~kg} \mathrm{ha}^{-1} \mathrm{~S}$. Witschoreck \& Schumacher (2015) estimated the nutrient stock in different components of the biomass of E. saligna at 7 years-of-age with a density between 1111 and 1666 trees ha $^{-1}$, and found: $54 \mathrm{~kg} \mathrm{ha}^{-1}$ $\mathrm{N}, 7 \mathrm{~kg} \mathrm{ha}^{-1} \mathrm{P}, 55 \mathrm{~kg} \mathrm{ha}^{-1} \mathrm{~K}, 241 \mathrm{~kg} \mathrm{ha}^{-1} \mathrm{Ca}$, and $54 \mathrm{~kg} \mathrm{ha}^{-1} \mathrm{Mg}$. 


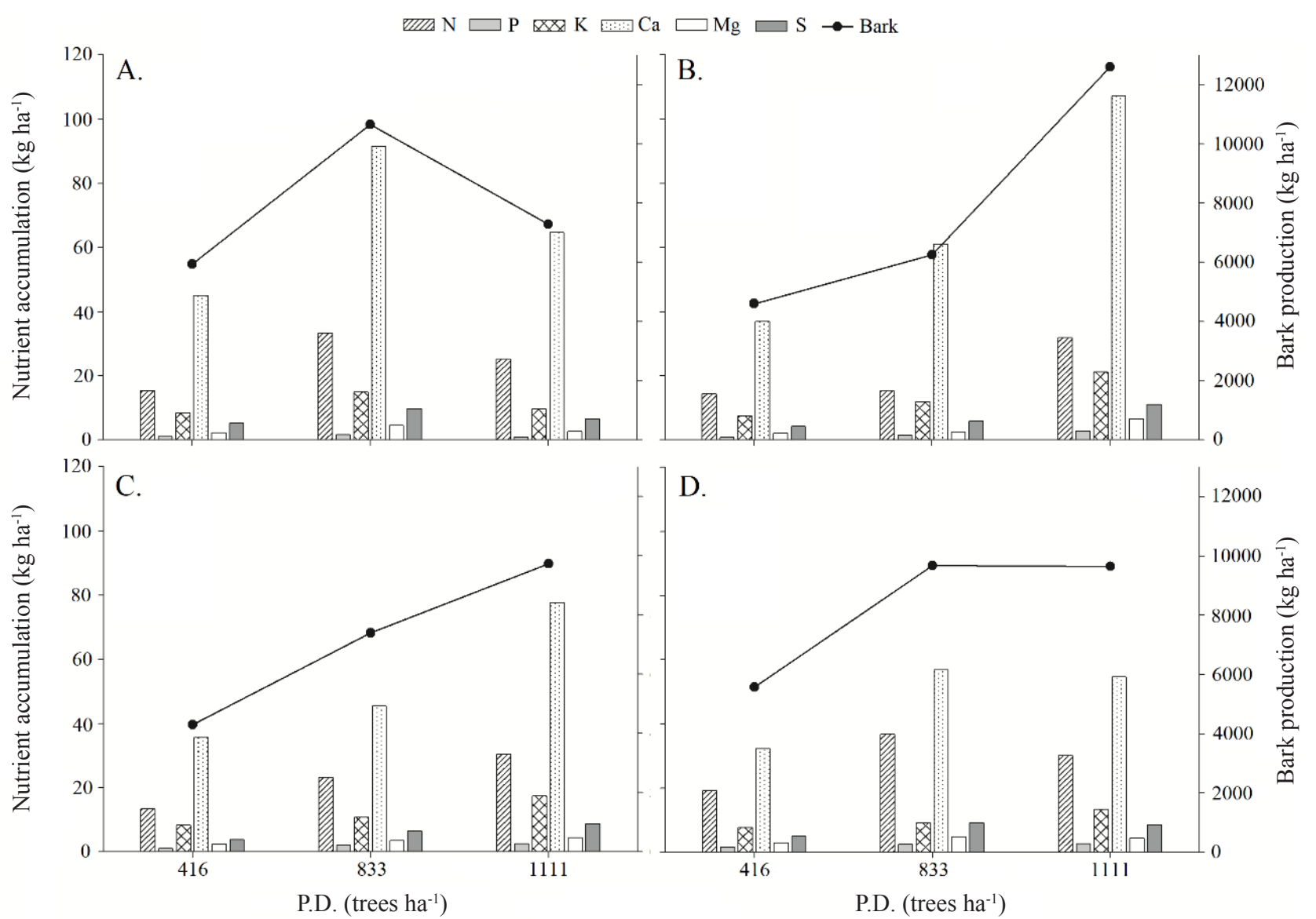

Figure 2. Nutrient accumulation in the bark $\left(\mathrm{kg} \mathrm{ha}^{-1}\right)$ and bark production $\left(\mathrm{kg} \mathrm{ha}^{-1}\right)$ of Eucalyptus clones 2486 (A), I182 (B), I144 (C), and GG100 (D), at 12 years-of-age, at three population densities - P.D. $(416,833$, and 1111 trees ha-1)

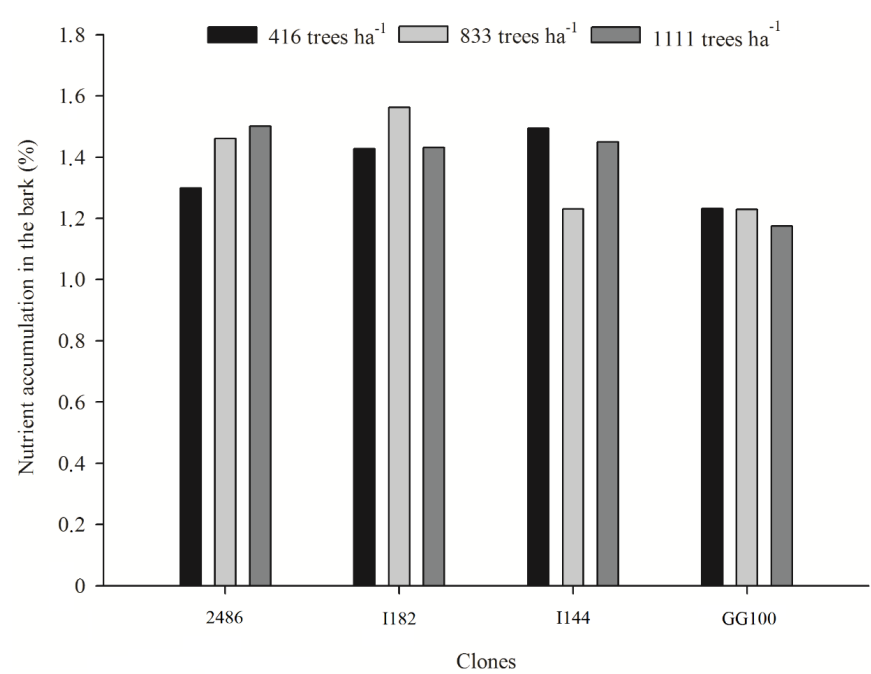

Figure 3. Nutrient accumulation (\%) in the bark of Eucalyptus clones 2486, I182, I144, and GG100, at 12 years-of-age, at three population densities $(416,833$, and 1111 trees ha-1)

Santana et al. (2008) studied the allocation of nutrients in Eucalyptus plantations at different ages and in different regions and observed: from 33 to $74 \mathrm{~kg} \mathrm{ha}^{-1} \mathrm{~N}$, from 5 to $10 \mathrm{~kg} \mathrm{ha}^{-1} \mathrm{P}$, from 30 to $83 \mathrm{~kg} \mathrm{ha}^{-1} \mathrm{~K}$, from 70 to $405 \mathrm{~kg} \mathrm{ha}^{-1} \mathrm{Ca}$, and from 12 to $46 \mathrm{~kg} \mathrm{ha}^{-1} \mathrm{Mg}$.

In this study, the values for each clone at the three planting densities were much lower. This difference can possibly be attributed to lower quality site conditions and low water availability in the study region, especially in the first 4 years (2004 to 2007), which were characterized by a long, dry season.
Santana et al. (2008) verified that the estimated nutrient content varies among regions, being up to five times lower in regions with lower water availability.

Furthermore, the older age of the forest stand in this study may have influenced results, since the nutrient content in the trunk was reduced, in accordance with the trees age (Reis \& Barros, 1990; Bouillet et al., 2008), which was reflected in the bark. Nevertheless, these results demonstrate the contribution of bark to nutrient accumulation, especially at sites with low productive capacity, such as those found in the northern Minas Gerais.

According to Witschoreck \& Schumacher (2015), a simple adjustment in the intensity of forest biomass harvesting through field debarking may represent the difference between a sustainable and damaging management of the nutrient reserves of the system.

Based on the calculation proposed by Barros et al. (1995), the amount of fertilizers equivalent to the concentrations of $\mathrm{N}, \mathrm{P}, \mathrm{K}$, and Ca in the bark of a forest stand with 416 trees ha $^{-1}$ is $118.5 \mathrm{~kg} \mathrm{ha}^{-1}$ of ammonium sulphate, $95.2 \mathrm{~kg} \mathrm{ha}^{-1}$ of simple superphosphate, $20.5 \mathrm{~kg} \mathrm{ha}^{-1}$ of potassium chloride, and 277.5 $\mathrm{kg} \mathrm{ha}^{-1}$ of dolomitic limestone, respectively. Similarly, for forest stands with 833 and 1111 trees ha ${ }^{-1}$, the amount of fertilizers is equivalent to 214.4 and $234.3 \mathrm{~kg} \mathrm{ha}^{-1}$ of ammonium sulphate, 207.7 and $274.3 \mathrm{~kg} \mathrm{ha}^{-1}$ of simple superphosphate, 30.2 and 40.0 $\mathrm{kg} \mathrm{ha}^{-1}$ of potassium chloride, and 478.3 and $574.8 \mathrm{~kg} \mathrm{ha}^{-1}$ of dolomitic limestone for $\mathrm{N}, \mathrm{P}, \mathrm{K}$, and $\mathrm{Ca}$, respectively.

Harvesting is considered to have the largest impact on the soil, and is aggravated by shorter rotations and the 
A.

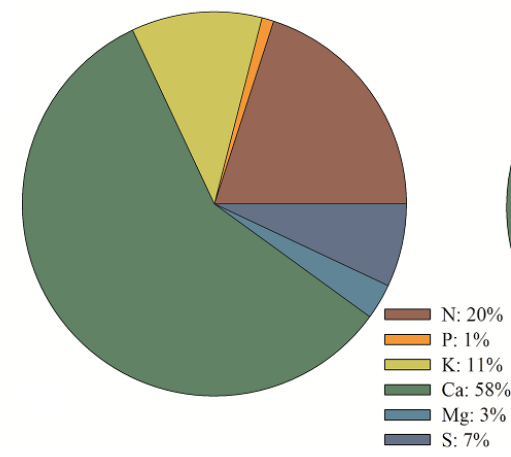

D.

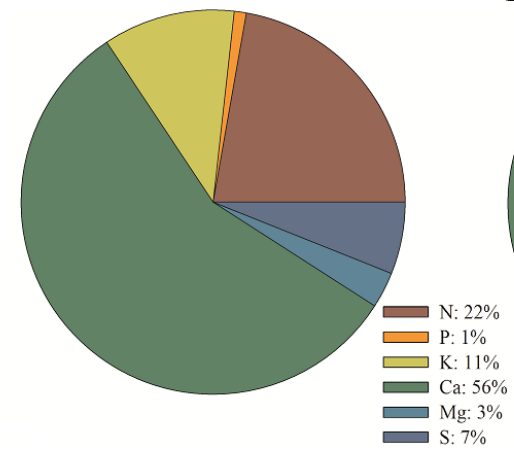

G.

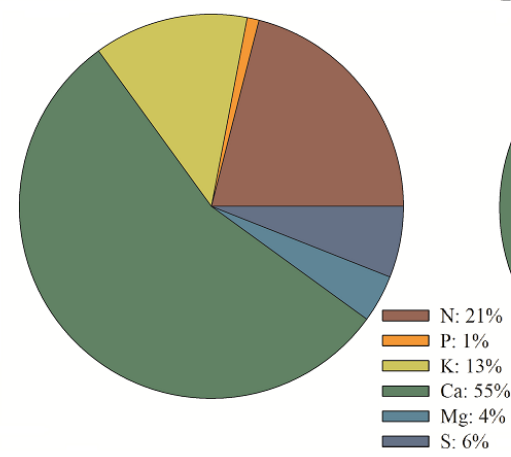

J.

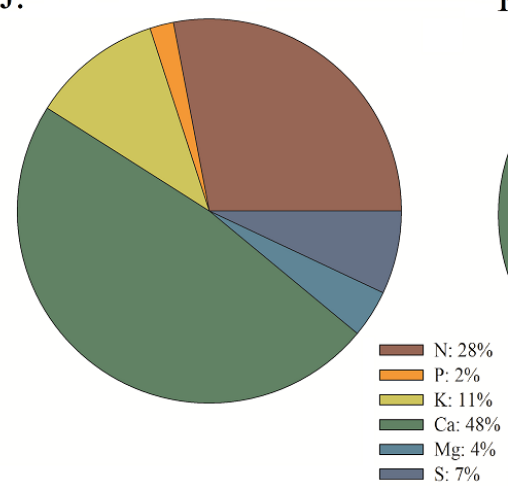

B.

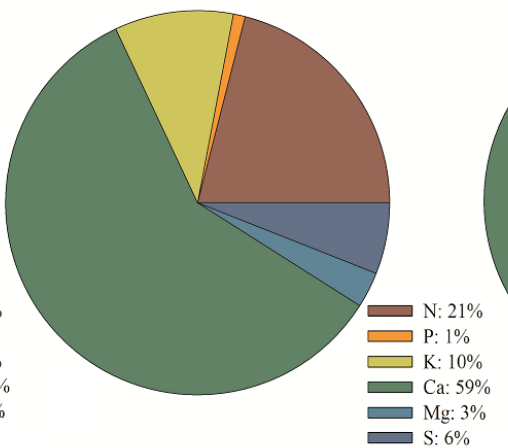

C.

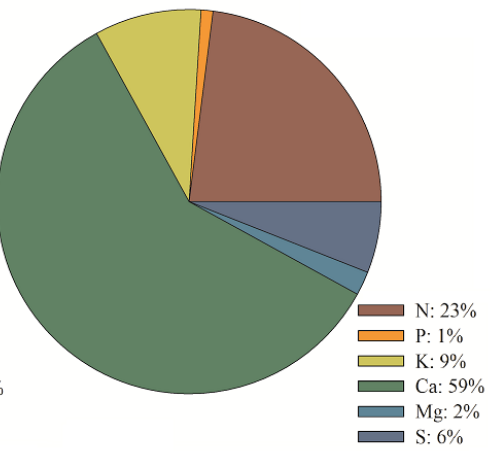

E.

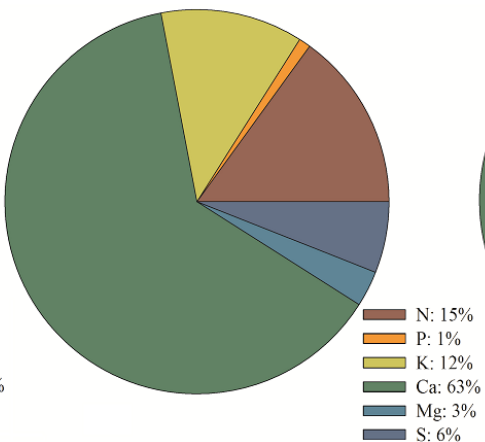

$\mathrm{H}$.

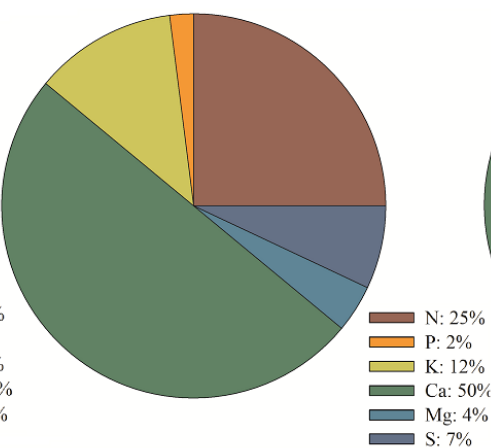

F.

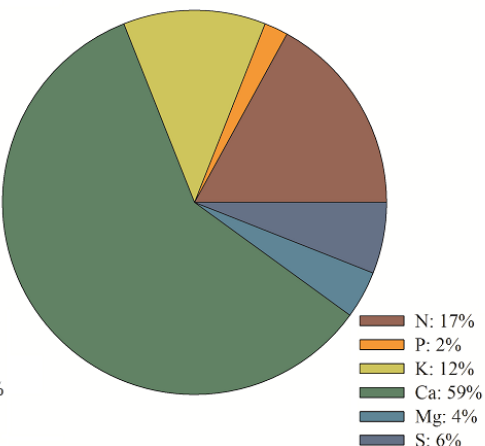

I.

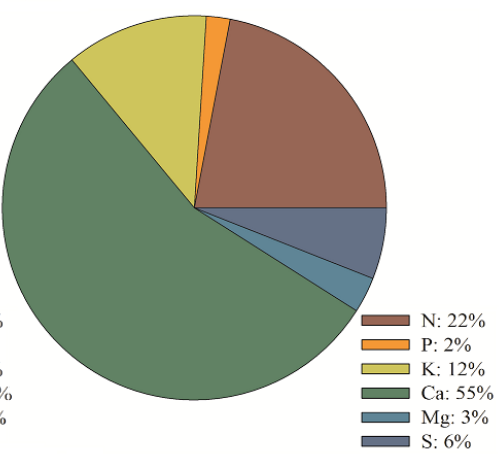

K.

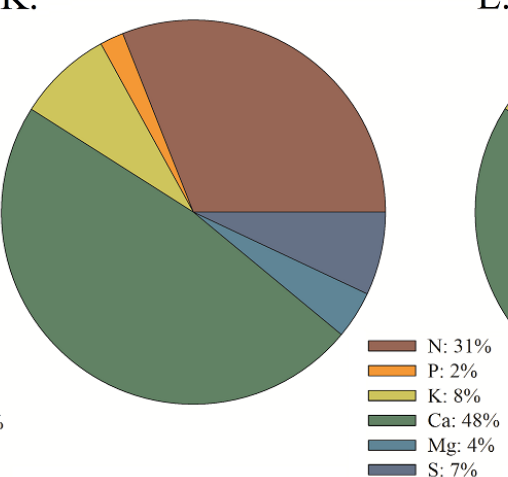

L.

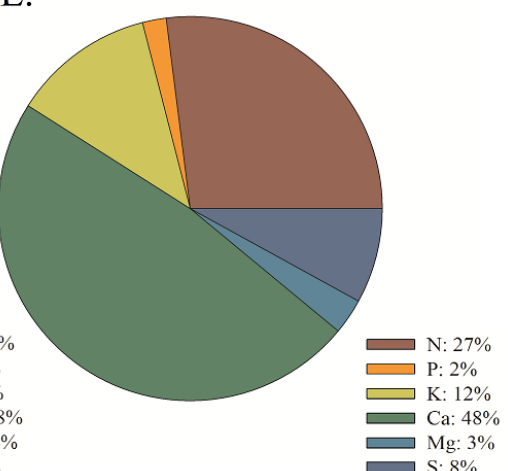

Figure 4. Nutrient accumulation (\%) in the bark of Eucalyptus clones at 12 years-of-age. Clone 2486 at (A) 416, (B) 833, and (C) 1111 trees ha-1. Clone I182 at densities (D) 416, (E) 833, and (F) 1111 trees ha- ${ }^{-1}$. Clone I144 at densities (G) 416, (H) 833, and (I) 1111 trees ha-1 ${ }^{-1}$ Clone GG100 at densities (J) 416, (K) 833, and (L) 1111 trees ha-1 $^{-1}$

export of nutrients. If the nutrient removal from logging is higher than the natural input of nutrients, the nutritional balance of the soil-tree system will be negative, reducing the productive potential of the area (Bellote et al., 2008; Paes et al., 2013). In this sense, these results show that the presence of bark in the field is an important component in reducing soil nutrient losses, especially at the highest population densities, which tend to have shorter cutting cycles with more frequent competition among trees anticipating the stagnation of the population growth, and allowing greater export of nutrients.

\section{Conclusions}

1. Ca showed the highest accumulation in the bark, followed by $\mathrm{N}, \mathrm{K}, \mathrm{S}, \mathrm{Mg}$, and $\mathrm{P}$, irrespective of clone and density. 
2. Higher population density contributed to a higher bark production and greater nutrient accumulation per area. However, this increase was not significantly different between the densities of 833 and 1111 trees ha ${ }^{-1}$.

3. The nutrient quantities exported from the site can be substantial, especially $\mathrm{Ca}, \mathrm{N}$, and $\mathrm{K}$, with removal of field bark during forest harvesting and at higher population densities.

4. The amounts of nutrients that are available for the next forest growth cycle are significantly less if there is debarking in the field.

\section{ACKNowledgements}

Authors thank the Foundation for Research Support of Minas Gerais (FAPEMIG) for the scholarship and the companies Plantar and TTG Brasil Investimentos Florestais for the technical and financial support.

\section{Literature Cited}

ABNT - Associação Brasileira de Normas Técnicas. NBR 11941 Madeira: Determinação de densidade básica. Rio de Janeiro: ABNT, 2003. 6p.

Alvares, C. A.; Stape, J. L.; Sentelhas, P. C.; Gonçalves, J. L. de M.; Sparovek, G. Köppen's climate classification map for Brazil. Meteorologische Zeitschrift, v.22, p.711-728, 2013. https://doi. org/10.1127/0941-2948/2013/0507

Arruda, O. G.; Tarsitano, M. A. A.; Alves, M. C.; Giácomo, R. G. Comparação de custos de implantação de eucalipto com resíduo celulósico em substituição ao fertilizante mineral. Revista Ceres, v.58, p.576-583, 2011. https://doi.org/10.1590/S0034737X2011000500007

Barros, N. F.; Novais, R. F. Eucalipto. In: Ribeiro, A. C.; Guimarães, P. T. G.; Alvarez V., H. V. (eds.). Recomendações para o uso de corretivos e fertilizantes em Minas Gerais: $5^{a}$ aproximação. Viçosa: Comissão de Fertilidade do Solo do Estado de Minas Gerais, 1999. Cap.18, p.303-305.

Barros, N. F. de; Novais, R. F. de; Teixeira, J. L.; Fernandes Filho, E. I. Nutricalc 2.0: Sistema para calculo del balance nutricional y recomendacion de fertilizantes para el cultivo de eucalipto. Bosque, v.16, p.129-131, 1995. https://doi.org/10.4206/ bosque.1995.v16n1-16

Bellote, A. F. J.; Dedecek, R. A.; Silva, H. D. da. Nutrientes minerais, biomassa e deposição de serapilheira em plantio de Eucalyptus com diferentes sistemas de manejo de resíduos florestais. Pesquisa Florestal Brasileira, v.56, p.31-41, 2008.

Bouillet, J. P.; Laclau, J. P.; Gonçalves, J. L. M.; Moreira, M. Z.; Trivelin, P. C. O.; Jourdan, C.; Silva, E. V.; Piccolo, M. C.; Tsai, S. M.; Galiana, A. Mixed-species plantations of Acacia mangium and Eucalyptus grandis in Brazil: 2 - Nitrogen accumulation in the stands and biological $\mathrm{N}_{2}$ fixation. Forest Ecology and Management, v.255, p.3918-3930, 2008. https://doi.org/10.1016/j.foreco.2007.10.050

Colpini, C.; Travagin, D. P.; Soares, T. S.; Silva, V. S. M. Determinação do volume, do fator de forma e da porcentagem de casca de árvores individuais em uma Floresta Ombrófila Aberta na região noroeste de Mato Grosso. Acta Amazônica, v.39, p.97-104, 2009. https:// doi.org/10.1590/S0044-59672009000100010
Domec, J. C.; Ashley, E.; Fischer, M.; Noormets, A.; Boone, J.; Williamson, C.; King, J. S. Productivity, biomass partitioning, and energy yield of low-input short-rotation american sycamore (Platanus occidentalis L.) grown on marginal land: Effects of planting density and simulated drought. BioEnergy Research, v.10, p.903-914, 2017. https://doi.org/10.1007/s12155-017-9852-5

Gatto, A.; Barros, N. F. de; Novais, R. F. de; Costa, L. M. de; Neves, J. C. L. Efeito do método de preparo do solo, em área de reforma, nas suas características, na composição mineral e na produtividade de plantações de Eucalyptus grandis. Revista Árvore, v.27, p.635646, 2003. https://doi.org/10.1590/S0100-67622003000500006

Leite, F. P.; Barros, N. F.; Novais, R. F.; Sans, L. M. A.; Fabres, A. S. Relações hídricas em povoamento de eucalipto com diferentes densidades populacionais. Revista Brasileira de Ciências do Solo, v.23, p.9-16, 1999. https://doi.org/10.1590/S010006831999000100002

Malavolta, E.; Vitti, G. C.; Oliveira, S. A. de. Avaliação do estado nutricional das plantas: Princípios e aplicações. 2.ed. Piracicaba: Potafos, 1997. 319p.

Paes, F. A. S. V.; Lima, A. M. N.; Hakamada, R. E.; Barros, N. F. Impacto do manejo dos resíduos da colheita, do preparo do solo e da adubação na produtividade de eucalipto. Revista Brasileira de Ciências do Solo, v.37, p.1081-1090, 2013. https://doi.org/10.1590/ S0100-06832013000400025

R Core Team. R: A language and environment for statistical computing. 2016. Disponível em: <http://R-project.org $>$. Acesso em: Out. 2017.

Reis, M. G. F.; Barros, N. F. Ciclagem de nutrientes em plantios de eucalipto. In: Barros, N. F.; Novais, R. F. (eds.). Relação soloeucalipto. Viçosa: Folha de Viçosa, 1990. Cap.7, p.265-302.

Salvador, S. M.; Schumacher, M. V.; Viera, M.; Stahl, J.; Consensa, C. B. Biomassa e estoque de nutrientes em plantios clonais de Eucalyptus saligna Smith em diferentes idades. Scientia Forestalis, v.44, p.311-321, 2016. https://doi.org/10.18671/scifor.v44n110.04

Santana, R. C.; Barros, N. F. de; Neves, J. C. L. Eficiência de utilização de nutrientes e sustentabilidade da produção em procedências de Eucalyptus grandis e Eucalyptus saligna em sítios florestais do estado de São Paulo. Revista Árvore, v.26, p.447-457, 2002. https:// doi.org/10.1590/S0100-67622002000400007

Santana, R. C.; Barros, N. F.; Novais, R. F.; Leite, H. G.; Comerford, N. B. Alocação de nutrientes em plantios de eucalipto no Brasil. Revista Brasileira de Ciências do Solo, v.32, p.2723-2733, 2008. https://doi.org/10.1590/S0100-06832008000700016

Schneider, P. R.; Schneider, P. S. P. Introdução ao manejo florestal. 2.ed. Santa Maria: FACOS-UFSM, 2008. 566p.

Selle, L. G. Ciclagem de nutrientes em ecossistemas florestais. Bioscience Journal, v.23, p.29-39, 2007.

Silva, E. A.; Silva, C. A.; Marques, J. J. G. S. M.; Curi, N.; Silva, I. R.; Araujo, E. F.; Carvalho, S. A.; Silva, S. H. G. Frações de carbono em topossequências de solos sob eucalipto com diferentes históricos de uso. Revista Brasileira de Ciências do Solo, v.36, p.1167-1178, 2012. https://doi.org/10.1590/S0100-06832012000400011

Viera, M.; Schumacher, M. V.; Truby, P.; Araujo, E. F. Implicações nutricionais com base em diferentes intensidades de colheita da biomassa de Eucalyptus urophylla x Eucalyptus globulus. Ciência Rural, v.45, p.432-439, 2015. https://doi.org/10.1590/0103$8478 \mathrm{cr} 20120367$ 
Wernsdörfer, H.; Jonard, M.; Genet, A.; Legout, A.; Nys, C.; SaintAndré, L.; Ponette, Q. Evidence for an additional site-age effect in the case of Fagus sylvatica. Forest Ecology and Management, v.330, p.192-204, 2014. https://doi.org/10.1016/j.foreco.2014.07.006
Witschoreck, R.; Schumacher, V. M. Alocação de nutrientes em povoamentos de Eucalyptus saligna Sm. na região de Guaíba-Rio Grande do Sul. Cerne, v.21, p.625-632, 2015. https://doi.org/10.1 $590 / 01047760201521041963$ 